\title{
Rare Animal Education Usingaugmented Reality
}

\author{
Hening Artdias \\ Information System Department, Faculty of Computer Science \\ Soegijapranata Catholic University, Indonesia \\ 13070036@student.unika.ac.id \\ Ridwan Sanjaya \\ Information System Department, Faculty of Computer Science \\ Soegijapranata Catholic University, Indonesia \\ Alb. Dwi Yoga Widiantoro \\ Information System Department, Faculty of Computer Science \\ Soegijapranata Catholic University, Indonesia
}

\begin{abstract}
Indonesia has a lot of the diversity in flora and fauna that can be assets and icon on this area. Unfortunately, flora and fauna that exist in Indonesia aredecreasing. The animals endangered in Indonesia are Javan Rhino, Sumatran Rhino, Sumatran Tiger, Sumatran Orangutan, Sumatran Elephant, Borneo Elephant, Bornean Orangutan and Turtle.

They are almost extinct because the destruction of forest habitats, a conflict between humans and animals, trade, hunting, and the arrests beyond capacity. [1]. The issue of the extinction of the animals is dominated by human behavior and nature wrath. For that reasons, education game "Rare Animal" becomes formulations to raise awareness of endangered species.
\end{abstract}

Keyword: education game, Augmented Reality, rare animal.

\section{INTRODUCTION}

Javan Rhino, Sumatran Rhino, Sumatran Tiger, Sumatran Orangutan, Sumatran Elephant, Borneo Elephant, Bornean Orangutan and Turtle are threatened to extinct because of the destruction of forest habitats, a conflict between humans and animals, trade, hunting, and the arrests beyond capacity
[1]. The issue of the extinction of the animals is dominated by human behavior and nature wrath. For that reasons, education game "Rare Animal" becomes formulations to raise awareness of rare animal.

Technology Augmented Reality, the utilization of with enjoyable gaming $3 \mathrm{D}$, is the formulations that are applied to interactive learning in the fun education game. The rare animal made like a real in modeling in three dimensions of the animal information, so players can identify the animals without necessarily visiting the conservation of rare animal. According to research by a team of Neurobiology at the University of California, playing games with 3D graphics can improve memory because gamers get more information that can be explored, and game with three dimension are more complex for a lot of information that can be learned [2]. It is the reason that "Augmented Reality"content information makes players easy to remember. 


\section{LITERATURE REFERENCES}

\subsection{Augmented Reality}

According to the language term, Augmented Reality is the reality in the paper media or marker. Augmented Reality is different from virtual reality.Augmented Reality is the integration of elements of digital in the real world [3]. This technology has been in existance for 40 years after their introduction of Virtual Reality. As a result of research about Augmented Reality that is Head-Mounted Display (HMD) is weapon of the fundamental technology [4]. According to the book "Mudah Membuat Game Augmented Reality (AR) dan Virtual Reality (VR) dengan Unity 3D”,Augmented Reality isa technique combining the virtualtwo dimensionsorthreedimensionsto the real then projecting the objects in real[5].

AR is a technology that combines a virtual $3 \mathrm{D}$ and $2 \mathrm{D}$ in the real world then project things virtual in real time. A virtual cannot be seen by people without the tools. AR also potentially eliminates things that have existed by adding a layer of the virtual[6].

\subsection{Unity 3D}

Unity $3 \mathrm{D}$ is a game engine to explore creativity in making video games, project unity could be exported on platform iPhone, Nintendo WiiWare, Android, PS3, Xbox Live Arcade. The 3D engine has the ability to make virtual environment in realtime and realistic as if users in the real world.[7]. The most important thing when making a project Augmented Reality in unity:

a. Project is a package of the components that also contains the identity of the project name, platform building and components that will be chosen.

b. Scene is the work for the manufacture. One scene can contain a few games,and with each other scene can be picked up differently.

c. Asset and Package are a collection of materials stored in the form of terrain, the game up and so forth.

d. Vuforia SDK is a device for the manufacture of Augmented Reality in order to track image target/marker[8].

\subsection{Ds Max}

3Ds Max can be used as anobject designer in 3D [9]. 3Ds Max is a program used professionally for architects, the development of game, animation, civil engineering and professional concerned. It can provide the ideal of real, deserves to be used as medium of learning.

\subsection{Educational Game}

Andang Ismail states that the educational gameisfun activities that characteristic to educate as it can be read in the book with the title Education Games [10].

\section{RESEARCH METHODOLOGY}

The location of thiseducation game research was in Kab.Semarang with the subjectsof 9-12 years old children. According to Erik Erikson, the development of psychosocial children 6-12 years is Industry vs. Inferiority.Children aged 6-12 years create a positive and being able to compete with the positive orientation [11]. The brain growth develops in accordance with the growth of the body. When a child reaches 5 years old, the growth of his brain has $80 \%$ of perfection. When a child is aged 6 years old, the process of brain growth can be said to have perfection[12].

Selection of children in vulnerable age 9-12 will support the research because the subject can read, write and understand the independent. The choice of location in Kab.Semarang is because it is close to a mountain which has natural wildlife and beautiful nature. This education games can 
prevent the action tonot disrupt the ecosystem of wild animals in the area. Population the study is Childrenaged 9 to 12 years old. The number of respondents is41 children.

Table 1. According To The Central Statistic of Semarang in 2014

\begin{tabular}{|c|c|c|c|}
\hline \multicolumn{4}{|c|}{ Population } \\
\hline \multicolumn{3}{|c|}{ In Kabupaten Semarang 2014} \\
\hline \multirow{2}{*}{ Age } & \multicolumn{3}{|c|}{ Kind of Sex } \\
\cline { 2 - 4 } & M & F & M F \\
\hline$(1)$ & $(2)$ & $(3)$ & $(4)$ \\
\hline $0-4$ & 35,632 & 33,602 & 69,234 \\
\hline $5-9$ & 40,331 & 37,718 & 78,049 \\
\hline $10-14$ & 41,844 & 39,334 & 81,178 \\
\hline $15-19$ & 39,797 & 39,891 & 79,688 \\
\hline $20-24$ & 35,330 & 42,066 & 77,396 \\
\hline $25-29$ & 39,583 & 42,611 & 82,194 \\
\hline $30-34$ & 38,794 & 39,559 & 78,353 \\
\hline $35-39$ & 35,739 & 36,769 & 72,508 \\
\hline $40-44$ & 35,605 & 36,122 & 71,727 \\
\hline $45-49$ & 31,409 & 32,532 & 63,941 \\
\hline $50-54$ & 28,722 & 28,526 & 57,248 \\
\hline $55-59$ & 22,071 & 20,081 & 42,152 \\
\hline $60-64$ & 13,704 & 14,874 & 28,578 \\
\hline $65-69$ & 10,676 & 12,577 & 23,253 \\
\hline $70-74$ & 9,778 & 12,451 & 22,229 \\
\hline $75+$ & 12,056 & 15,697 & 27,753 \\
\hline Total & 471,071 & 484,410 & 955,481 \\
\hline 2014 & & & \\
\hline
\end{tabular}

\section{RESULT AND EXPLANATION}

It is the content game "Rare Animal"

1. Opening Opening has contents of education information: the number of animals and the reasons why the animals are extinct.

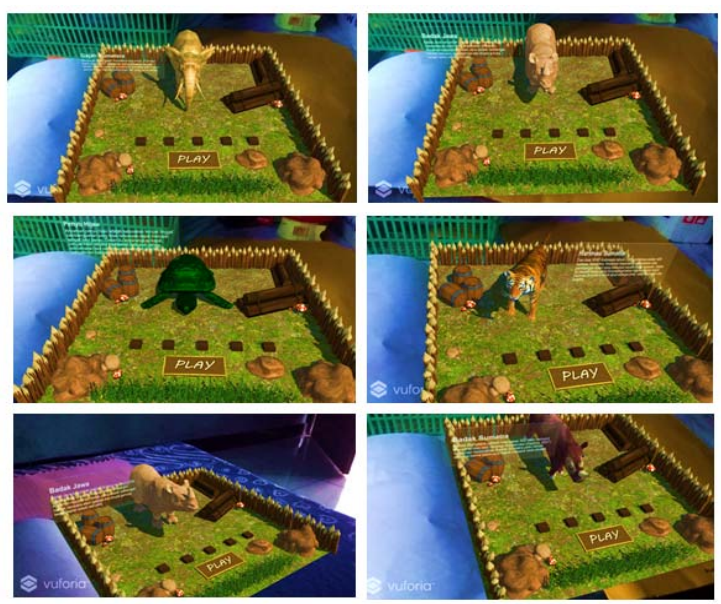

2. Lever 1

Level 1, the player is servedto liberate the rhino of the cage to save Rhino Javan and Rhinos Sumatran with a few clues to solve it.

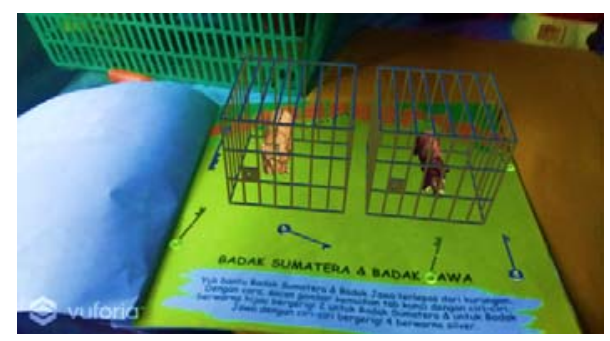

Figure 2 Level 1 Rare Animal

3. Level 2

Level 2, the player is assigned to extinguish the forest fire to protect the species and habitat.

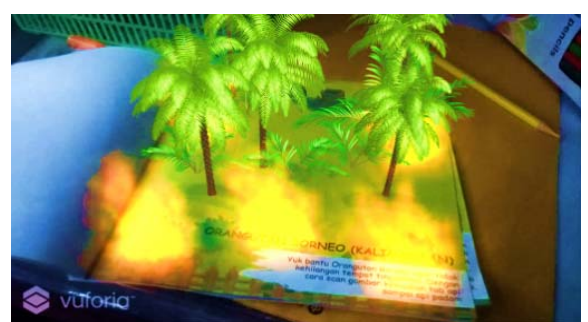

Figure3Level 2 Rare Animal 
4. Level 3

Level 3, the player is assigned to save the Sumatran Elephants in order not to starve, mines as a challenge.

5.

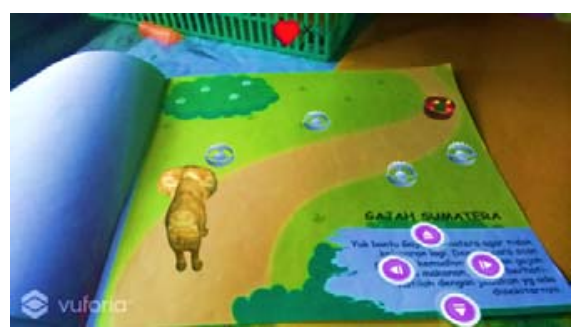

9. 10.

$$
\text { Figure4Level } 3 \text { Rare Animal }
$$

5. Level 4

Level 4, the player is assigned to clean the garbage on the beach because green turtles often produce waste and garbage.

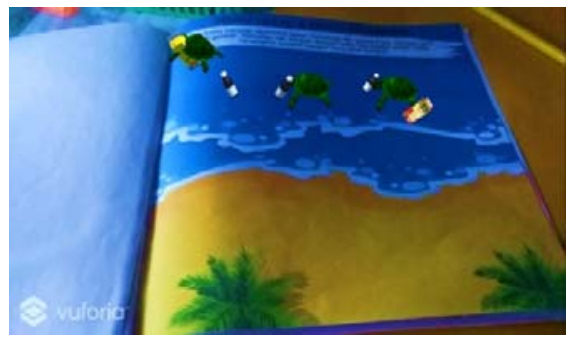

Figure5Level 4 Rare Animal

6. Level 5

Level 5 is a quiz to guess the origin of animals so that the player knows more about wildlife habitat.

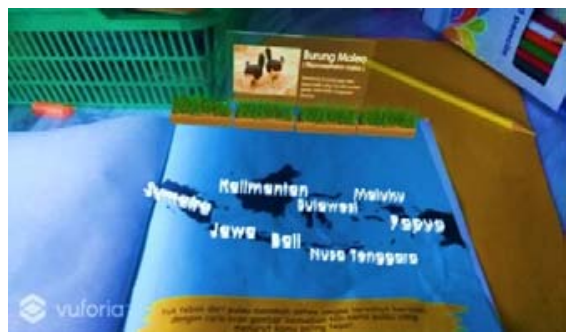

Figure6Level 5 Rare Animal

\section{Gift}

It is used to appreciate the player to finish the game in order to attract the player to play until the end of game.

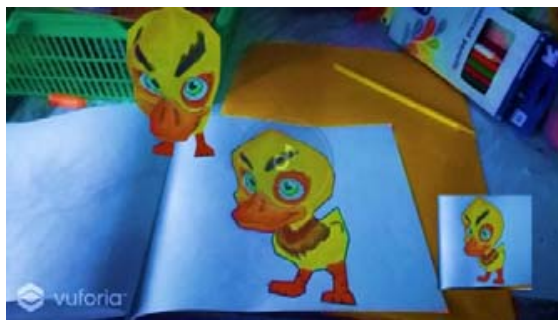

Figure 7Gift Rare Animal

The result showed that 41 respondents answered the questionnaires:

1. Do you like the game " Rare Animal "?

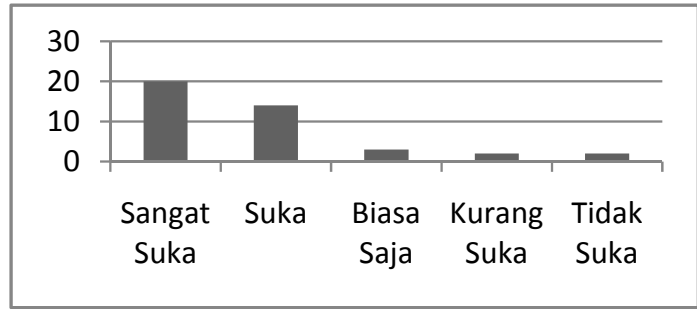

Figure 8 Diagram of The Analysis In Interest 1

There were 20 people who really liked the game, 14 people liked, 3 people chose fair, two people likeda bit, and two people didn't like it. 
2. Do you like the game with 3 Dimensions based on Augmented the reality?

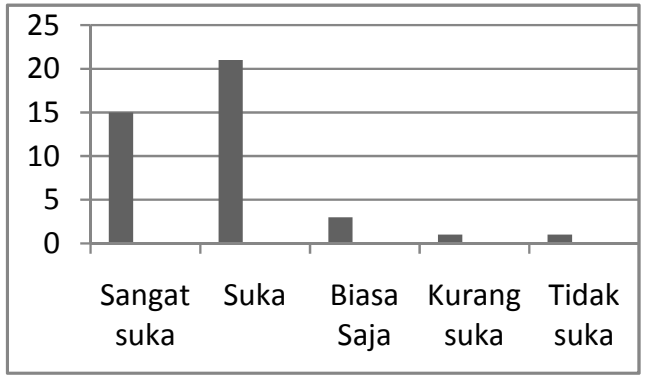

Figure 9 Diagram of The Analysis In Interest 2

There were 15 people who really liked, 21 people liked, three people chose fair, one liked a bit, and a person did not like.

3. Are you excited in playing game "Rare Animal”?

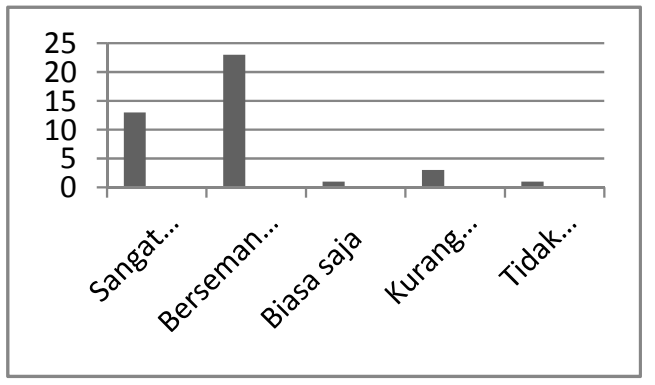

Figure 10 Diagram of The Analysis In Interest 3

There were 13 respondents who were very excited, 23 excited respondents, one fair, 3 less excited, and one not excited.

4. Do you want to invite your friend to play game "Rare Animal”?

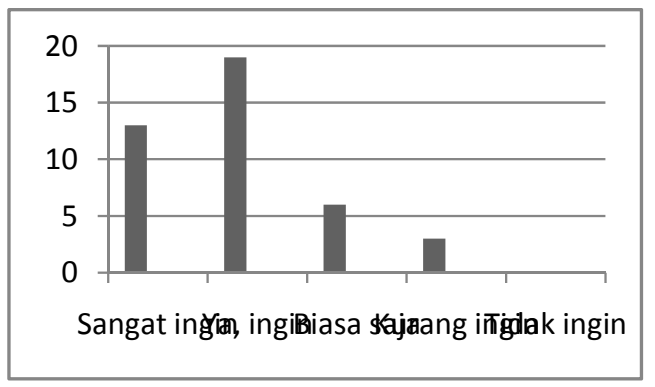

Figure 11 Diagram of The Analysis In Interest 4
There were 13 of 41 respondents declared that they really wanted to take theirfriends to play the game "Rare the Animal", 19respondents wanted to invite, 6 respondents chose fair, and 4 respondentswere reluctant to invite.

5. Do you agree to study rare animals after playing "Rare Animal”?

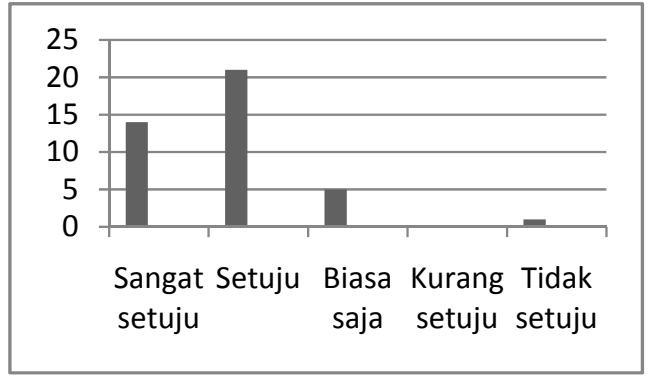

Figure 12 Diagram of The Analysis Game Can Be Fun Interactive Learning 1

There were 14 of 41 respondents who strongly agreed to study, 21 respondents agreed, 5 respondents were fair, and one respondent did not agree.

6. Do you think the game "Rare Animal" can make it easier to remember any information?

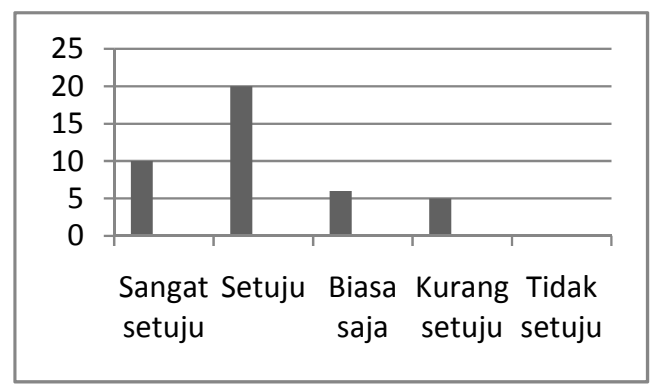

Figure 12 Diagram of The Analysis Game Can Be Fun Interactive Learning 2

There were 10 of 41 respondents who strongly agreed, 20 respondents agrees, 6 respondents chose fair, and 5 respondents didn’t think it was easy. 
7. Do you think playing the game "Rare Animal"is fun?

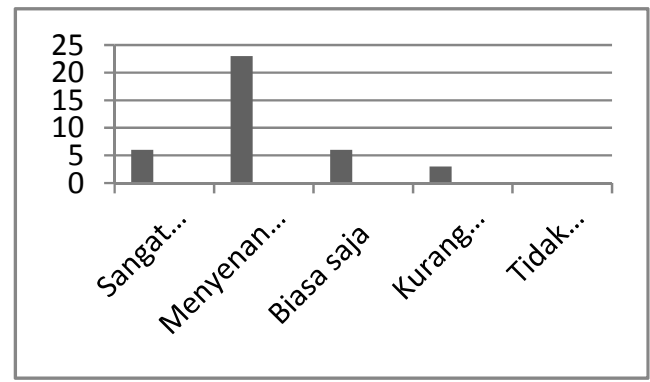

Figure 13 Diagram of The Analysis Game Can Be Fun Interactive Learning 3

There were9 of 41 respondents who answered a lot of fun, 23 respondents answered yes, 6 respondents said fair, 3 respondents didn’t quite like.

\section{CONCLUSION}

The game using augmented reality that is packaged in the "Rare the Animal" is able to increase the interest of children's play because they feel interested in how to play the game that was not monotonous. Based on the data analysis, $90 \%$ respondents loved the game in $3 \mathrm{D}$ based Augmented the reality.

The technology of "Rare Animal" game uses augmented reality based OS the androids that can be played, not just carry up the 3D. The system rewards in the form of next stage and at the end, inbuilt reward for coloring the $3 \mathrm{D}$ texture to appreciate complete game. The game can be interactive learning in a fun way.

The "Rare the Animal" game shows that a concern for endangered species increases after playing games.Respondents know what to do in endangered species and habitat with the real story, the main reasons of the animal crisis. Pre-test score was 619 and Post-test increased to 840 .
"Rare the Animal" Game has 5 of the trigger or marker. The game can only be played if a jet. Marker of two dimensions can tobe print out to be able to do the scan on so it can bring out the game. ????????????????????????

"Rare Animal" Game can only be played under the specification of the smartphone. The specifications of the back camera are at least 8 MegaPixel with RAM at least $1 \mathrm{~GB}$ and OS Android JellyBean. If not, the game will fail loading and the 3D will not show up.

\section{ACKNOWLEDGEMENTS}

The writing of this manuscript was made possible by a grant provided through the Excellent Scholarship ofDirectorate General of Higher Education, Ministry of Education and Culture of the Republic of Indonesia

\section{REFERENCES}

[1] WWF-Indonesia, "Species," WWFIndonesia. [Online]. Available: http://www.wwf.or.id/program/spesies/

[2] G. Alif, "Sudi: Game 3D Tajamkan Daya Ingat,” detikInet, 2015. [Online]. Available:

https://inet.detik.com/games-news/d3102295/studi-game-3d-tajamkandaya-ingat.

[3]T. R. Annastacia Novianti Priyatna, Lisa Triana Putri, Mora Parlindungan, "Implementasi Augmented Reality Sebagai Media Pembelajaran Pada Simulasi Terjadinya Tsunami,” EJournal Univ. Gunadarma, p. 24, 2013. 
[4] R. S. Andre Kurniawan, Maryuni, Mudah Membuat Game Augmented Reality (AR) dan Virtual Reality (VR) dengan Unity 3D. Kompas Gramedia Building, 2016.

[5] M. Chafied, "Brosur Interaktif Berbasis Augmented Rality," eJournal ITSN, pp. 1-5, 2010.

[6]W. H. dan E. W. Eka Ardhianto, “Augmented Reality Objek 3 Dimensi dengan Perangkat Artoolkit dan Blender,” Pros. SNATIF, pp. 267-274, 2014.

[7] Y. Appli Muhamadan Jeba, Andika Ocfera, "Rancang Bangun Aplikasi Edugame Museum Sultan Mahmud Badaruddin II Palembang Berbasis Unity 3D,” JATISI MDP, no. x, pp. 110, 2012.

[8] K. T. M. Iwan Setya Nugraha, Kodrat Iman Satoto, "Pemanfaatan Augmented Reality Untuk Pembelajaran Pengenalan Alat Musik Piano,” SISKOM UNDIP, p. 9, 2009.

[9] S. Hutamaputra and D. - I. F. Thalib, "Pembuatan Sistem Pakar Untuk Diagnosis Penyakit Telinga Dengan Menggunakan SHARPDEVELOP dan 3Ds MAX,” E-Journal Univ. Gunadarma, pp. 1-16, 2010.
[10]A. Ismail, Education Games. Yogyakarta: Pilar Media, 2006.

[11] M. Hasan, PAUD (Pendidikan Anak Usia Dini). 2009.

[12] Badan Pusat Statisik Indonesia, “Jumlah Penduduk Menurut Kelompok Umur dan Jenis Kelamin di Kabupaten Semarang Tahun 2014,” 2014. [Online]. Available: http://semarangkab.bps.go.id/linkTabe IStatis/view/id/21. 